\title{
ANALYSIS OF CADMIUM (Cd) LEVELS AND HISTOPATHOLOGY OF MYSTUS NIGRICEPS IN DOWNSTREAM WATER AT THE GEMBONG RIVER OF PASURUAN, EAST JAVA, INDONESIA
}

\author{
Valina Rahmi ${ }^{\star}$, Herawati Endang Yuli, Mahmudi Mohammad \\ Department of Aquatic Resource Management, Faculty of Fisheries and Marine Science, \\ University of Brawijaya, Indonesia \\ *E-mail: rahmivalina04@gmail.com
}

\begin{abstract}
Heavy metals have high toxicity that can cause water pollution. Cadmium $(\mathrm{Cd})$ level in the water can interfere with fish physiology and result in excessive oxidative stress. Histopathological damage to the fish organs can use as a biomarkers providing early warning of environmental changes due to toxicants. This research was conducted in March - April 2021 using the survey method. Sampling was carried out three times a span of every two weeks at three stations along downstream water of the Gembong River, Pasuruan, East Java. Parameters observed included heavy metal content of $\mathrm{Cd}$ in the water and Mystus nigriceps organs, histopahtology of the liver, kidneys, and gill of Mystus nigriceps, and water quality as supporting data (temperature, $\mathrm{pH}, \mathrm{DO}$, and COD). Observation result of the heavy metal level of $\mathrm{Cd}$ in the water and Mystus nigriceps organs have exceeded the specified threshold. Tissue damage to the liver, kidneys, and gills as necrosis, cell degeneration, and hyperplasia mild to moderate. The highest damage was found at station three, each damage value of $70.7 \%$ liver, $59.9 \%$ kidney, and $70.9 \%$ gills. Water quality measurements result of temperature, $\mathrm{pH}, \mathrm{DO}$ and COD still optimal supporting fish life. Based on the resulting study, it can conclude that there is a relationship between the amount of damage and the Cd levels in the water and Mystus nigriceps organs. The higher Cd level caused higher damage to the organs.
\end{abstract}

\section{KEY WORDS}

River, water pollution, heavy metal cadmium, histopathology, Mystus nigriceps, water quality, management of the water resources.

Gembong River is one of the rivers located in the middle of Pasuruan city, flowing and disembogued to Madura Strait (KKS Pasuruan, 2015). When going downstream, there is a change in the land use around the river. It is usually used for cultivation areas, agriculture, fisheries, residential areas as well as industrial areas (Safitri et al., 2019). The high of human activity can produce the waste products like heavy metals that can cause river pollution.

Heavy metal is one of the dangerous pollutants in the environment because it has the highest toxicity and accumulated on organism body. Heavy metals enter aquatic ecosystems through natural sources and anthropogenic activities. If it continues, it will have an impact on the aquatic environment. Because it cannot be decomposed and biomagnification occurs through the food chain (Mustafa, 2020). One of the heavy metals that are toxic to aquatic biota is cadmium (Cd). Cd toxicity can cause physiological disturbances and excessive oxidative stress (Hossain et al., 2021).

Fish is a better biomarker that can reduce early warning for changes and the environmental effect caused by toxicants (Hussain et al., 2018). To indicate the health status of the fish, it can see from the tissues damage of the fish organs. Histopathology of the fish vital organs, namely liver, kidneys, and gill are often used as biomarkers to indicate health status in stress conditions because of pollution (Hossain et al., 2021).

Mystus nigriceps is a freshwater organism that can survive in a polluted aquatic environment, including low oxygen levels and high turbidity. These fish include omnivorous fish and tend to be carnivorous that become top consumers in the food chain who are at risk of exposure to heavy metals in their food (Anggitasari et al., 2019). The purpose of this study 
was to analyze the heavy metals content of $\mathrm{Cd}$ in the water and organs and to observe histopathological tissues damage in the Mystus nigriceps organs in the downstream of the Gembong River, Pasuruan, East Java.

\section{MATERIALS AND METHODS OF RESEARCH}

This study uses a survey method with descriptive data analysis. The quotation of the sampling location is based on the purposive method based on the land use. There are three sampling stations, station one is an agricultural and fishery area, station two is a residential area, and station 3 is an industrial and port area.

Mystus nigriceps was obtained from a local fisherman by angling using a hand line. Then, fish dissected to take the liver, kidneys and gill to see damage status. Histological preparations were using paraffin method and Haemotoxylin-Eosin (HE) staining at the Anatomy and Histology Laboratory, Faculty of Medicine, University of Brawijaya. Measurement of $\mathrm{Cd}$ heavy metal levels in the water and fish organs uses the Atomic Absorption Spectrophotometry (AAS) method at the Chemistry Laboratory, Faculty of Mathematics and Science, University of Brawijaya. In addition, to measure Cd heavy metal levels, physical and chemical water quality measurements were carried out by supporting data such as temperature, $\mathrm{pH}$, Dissolved Oxygen (DO) and COD that measured according to SNI Procedures.

Data analysis used the descriptive method. Descriptive analysis was carried out data on heavy metal $\mathrm{Cd}$ contamination in water, and fish organs, histopathological damage to organs and water quality data. Analysis of heavy metal content in organs compared with the quality standard of SNI No. 7387:2009 concerning Maximum Limits of Metal Contamination in Foodstuffs. Analysis of Cd heavy metal content in water and water quality compared with Water Quality Criteria Based on Class III Government Regulation No. 22 in 2021 concerning the Implementation of Environmental Protection and Management, while the histopathological damage data obtained were compared with normal histology of the liver, kidneys, and gills obtained from previous studies.

\section{RESULTS AND DISCUSSION}

Based on the result of the study, the concentration of Cadmium $(\mathrm{Cd})$ in downstream waters of the Gembong Rivers ranged from 0.08 to $0.33 \mathrm{mg} / \mathrm{L}$, the highest value at station three and the lowest at station 2 (Figure 1). Based on the Government Regulation of Republic of Indonesia No. 22 of 2021 concerns the implementation of environmental protection and management. Cd heavy metal level in the downstream water of the Gembong River has exceeded the third class water quality standard of $0.01 \mathrm{mg} / \mathrm{L}$. The high content of $\mathrm{Cd}$ at station three is because of an industrial and port area where industrial waste contains heavy metals high level. In addition, the port serves as a place for fishing vessels covered with $\mathrm{Cd}$ metal to stunt the corrosion process. High levels of heavy metals in the water can cause by accumulative impact of various industries such as printing, dyeing, leather industry, electroplating, and the other chemicals that produce wastes product directly or indirectly into river water (Saha et al., 2016). High Cd level existence in the water can affect other water parameters quality such as temperature and pH (Ferro et al., 2021).

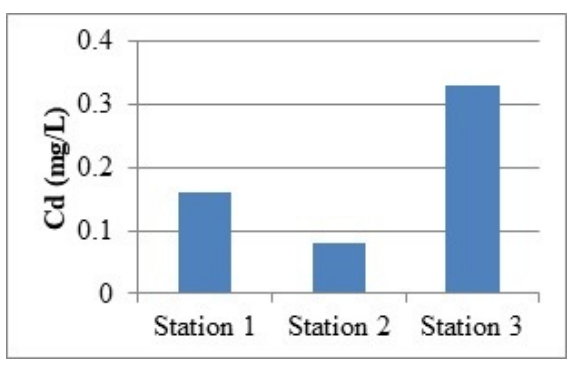

Figure 1 - Cadmium concentration 
The result of the analysis of $\mathrm{Cd}$ content in Mystus nigriceps organs on the liver, kidneys, and gills at three stations can see in Table 1. Cd heavy metals content in Mystus nigriceps organs at downstream water of the Gembong River, Pasuruan is above the quality standard threshold based on SNI 7389:2009 of $0.01 \mathrm{mg} / \mathrm{Kg}$. The biomagnification process in the water causes $\mathrm{Cd}$ concentration to continue to increase, resulting in the absorption of heavy metal content in fish (Baharom and Ishak, 2015).

Table 1 - Cd level in Mystus nigriceps organ

\begin{tabular}{lllll}
\hline No & Organ & Station 1 & Station 2 & Station 3 \\
\hline 1 & Liver & $1,39 \pm 0,00$ & $0,20 \pm 0,00$ & $3,61 \pm 0,16$ \\
2 & Kidneys & $0,32 \pm 0,00$ & $0,25 \pm 0,00$ & $0,38 \pm 0,00$ \\
3 & Gills & $0,21 \pm 0,00$ & $1,68 \pm 0,00$ & $5,24 \pm 0,17$ \\
\hline
\end{tabular}

Histopathological observations of Mystus nigriceps found some damage to the liver, kidneys, and gills. The damage is in the form of necrosis, degeneration, congestion, and hyperplasia of the gills. Contamination monitoring in fish histopathology serves as early warning indicator of contamination that enters the waterbody. Fish can absorb dissolved elements and heavy metals from the water and food around them. Heavy metals enter the fish body through the blood carry by the blood in direct contact with organs and tissues that can accumulate in various organs and tissues of fish (Abiona et al., 2019).

Based on microscopic observations, the result obtained are different level of liver damage at each station (Table 2). The highest damage to the liver was found at station 3 with a percentage of the damage of $70.7 \%$ indicating moderate damage status. While the lowest was found at station 2 of $36.8 \%$ with mild damage status. Histopathological changes in the liver of Mystus nigriceps at downstream of the Gembong River were necrosis, cell degeneration, and congestion (Figure 2). This study indicates that exposure to water pollution due to environmental stress from anthropogenic activities. Heavy metals with high concentrations in the waters can make changes in water quality that interferes with the physiology of aquatic biota which can cause organ damage.

Table 2 - Histopathology scoring in Mystus nigriceps liver

\begin{tabular}{llllll}
\hline \multirow{2}{*}{ Location } & Damage & & & \multirow{2}{*}{ Average (\%) } & \multirow{2}{*}{ Damage status } \\
\cline { 2 - 4 } & Nekrosis & Degenerasi & kongesti & & \\
\hline Station 1 & 36,6 & 36,3 & 59,6 & 44,2 & Mild \\
Station 2 & 57,6 & 41,6 & 11,3 & 36,8 & Mild \\
Station 3 & 98 & 75,6 & 38,6 & 70,7 & Medium \\
\hline
\end{tabular}

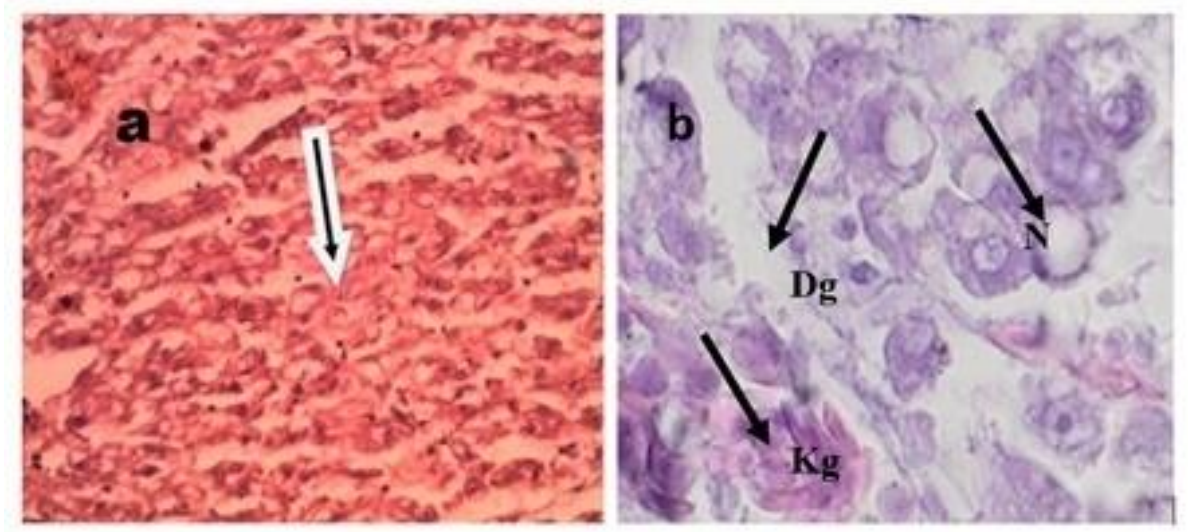

Figure 2 - a) Liver normal structure (Abiona et al., 2019); b) Mystus nigriceps liver damage Necrosis $(\mathrm{N})$, Cell degeneration $(\mathrm{Dg})$ and Congnestion $(\mathrm{Kg})$ (Source: Field Data)

The fish samples showed necrotic damage, degeneration, and congestion in the liver of Mystus nigriceps (Figure 2b). Inflammation may occur as a protective response to the tissues damage. Liver tissue has fatal physiological functions including metabolism of proteins, 
carbohydrates, and lipids, synthesis of plasma proteins such as albumen, and secretion of bile. Liver necrosis can occur due to the presence of heavy metals. Heavy metals are hepatotoxic (attack the liver), neurotoxic (attack nerves) and nephrotoxicants (attack the kidneys) then accumulate and interfere with enzyme (Sulistyawati et al., 2020). Fish exposed on cadmium can cause congestion and swelling of hepatocytes in the liver (Anggitasari et al., 2019).

Based on microscopic observations results, the level of kidney damage were different at each station (Table 3). The highest damage to the kidneys was at station three on a percentage of damage of $59.9 \%$ indicate moderate damage status, while the lowest was at station 2 of $45.6 \%$ with mild damage status. Histopathological changes in the Mystus nigriceps kidney downstream of the Gembong River were necrosis, cell degeneration, and congestion (Figure 3). Based on the damage status, it showed that the kidneys of Mystus nigriceps had been damaged due to exposure to toxic materials such as heavy metal $\mathrm{Cd}$. Heavy metal contamination can cause tubular and glomerular changes in the kidneys.

Table 3 - Histopathology scoring in Mystys nigriceps kidneys

\begin{tabular}{llllll}
\hline \multirow{2}{*}{ Location } & Damage & & & \multirow{2}{*}{ Average (\%) } & Damage status \\
\cline { 2 - 5 } & Nekrosis & Degenerasi & Kongesti & & Mild \\
\hline Station 1 & 44 & 46 & 56,7 & 48,9 & Mild \\
Station 2 & 31,33333 & 44 & 61,3 & 45,6 & Medium \\
Station 3 & 85,66667 & 59 & 35 & 59,9 & \\
\hline
\end{tabular}

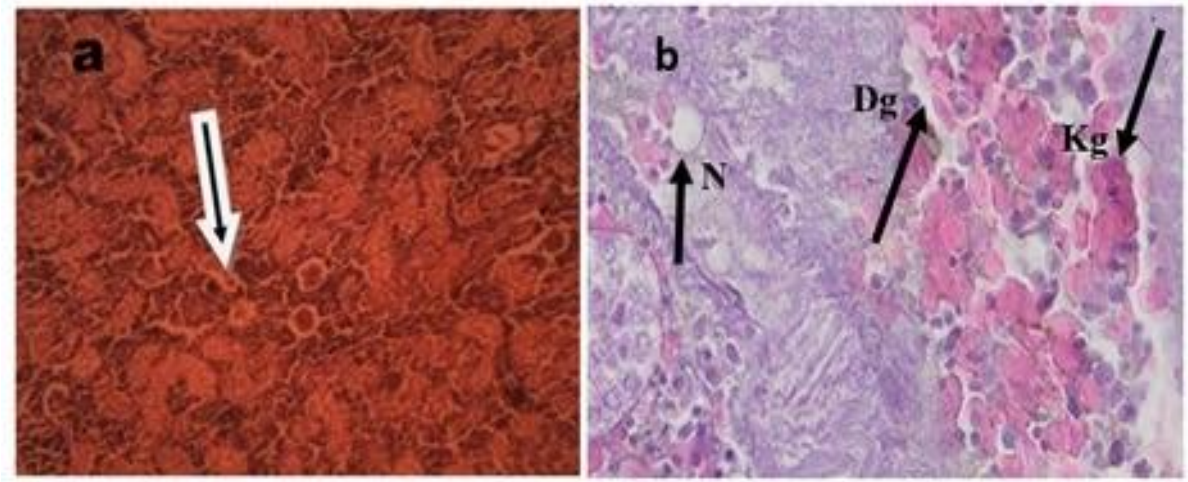

Figure 3 - a) Kidneys normal structure (Abiona et al., 2019); b) Mystus nigriceps kidneys damage Necrosis $(\mathrm{N})$, Cell degeneration( $\mathrm{Dg})$ and Congnestion $(\mathrm{Kg})$ (Source: Field Data)

The fish samples showed necrosis, degeneration, and congestion of the Mystus nigriceps kidneys (Figure 3b). The kidneys are one of the main organs that express toxic effects (Senarat et al., 2015). Damage to the kidneys exposed to toxicant materials can cause changes in distal tubular diameter, glomerular expansion, damage to kidney cells, degenerate of tubular cells, bleeding with the diffusion of erythrocytes in the interstitial fluid (Hadi and Alwan, 2012). The fatal change found in the renal glomerulus is the expansion of the glomerulus that causes the reduction in Bowman's space. The most frequent damage is cell swelling and hyaline degeneration. Less common damage is tubular regeneration (Camargo and Martinez, 2007).

Based on microscopic observations, different levels of gills damage were obtained at each station (Table 4). The highest damage to the gills was at station 3 with a percentage of damage of $70.9 \%$ indicate moderate damage status, while the lowest was at station 1 of $40.2 \%$ with mild damage status. Histopathological changes in the gills of Mystus nigriceps downstream of the Gembong River were necrosis, cell degeneration, and hyperplasia (Figure 4). Based on the damage status, it shows that the gills of Mystus nigriceps have been damaged due to exposure to toxic materials such as heavy metal Cd. Gills are organs susceptible to exposure to toxic materials from the environment because they are directly related to the aquatic environment. 
Table 4 - Histopathology scoring in Mystus nigriceps gills

\begin{tabular}{llllll}
\hline \multirow{2}{*}{ Location } & Damage & & & \multirow{2}{*}{ Average (\%) } & Damage status \\
\cline { 2 - 5 } & Nekrosis & Degenerasi & Hiperplasia & & \\
\hline Station 1 & 36,7 & 30,3 & 53,7 & 40,2 & Mild \\
Station 2 & 51,7 & 47,3 & 79,7 & 59,6 & Medium \\
Station 3 & 81,3 & 48,7 & 82,7 & 70,9 & Medium \\
\hline
\end{tabular}
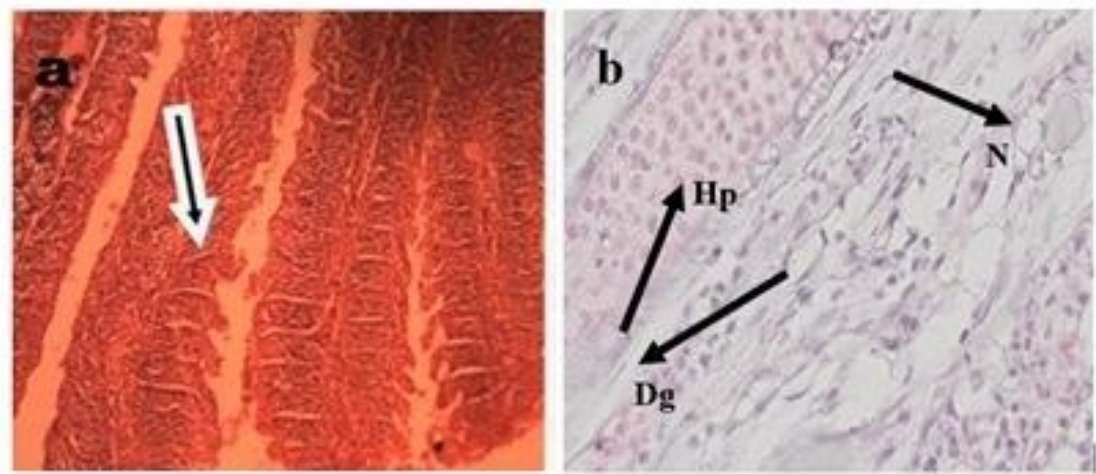

Figure 4 - a) Gills normal structure (Abiona et al., 2019); b) Mystus nigriceps gills damage Necrosis $(\mathrm{N})$, Cell degeneration $(\mathrm{Dg})$ and Congnestion $(\mathrm{Kg})$ (Source: Field Data)

The fish samples showed necrosis, degeneration, and hyperplasia of the gills of Mystus nigriceps (Figure 4b). Normal gill tissues and cells, the primary, and secondary lamellae of the gill filaments can be easily detected (Mohammed et al., 2016). Gills are fatal organs that have many functions as gas exchange, osmotic pressure, regulation, and acid-base balance. The damage that occurs in the gills is hyperplasia of the mucosal cells, edema of the secondary lamellae, and congestion of the gill blood vein (Puntoriero et al., 2018). Fish gills exposed to toxic substances will show gill edema, necrosis, changed in the secondary and primary lamellae accompanied by loss of epithelial cells (Madhulatha and Rajyasree, 2019). The measurement result of the physical and chemical parameters of water during the study can be seen in the table below (Table 5).

Table 5 - Physical and Chemical Parameters value of downstream in the Gembong River

\begin{tabular}{|c|c|c|c|c|c|}
\hline \multirow{2}{*}{ Parameter } & \multirow{2}{*}{ Unit } & \multirow{2}{*}{ PP No.22 of 2021 Class III quality standard } & \multicolumn{3}{|c|}{ Station } \\
\hline & & & 1 & 2 & 3 \\
\hline Temperature & ${ }^{\circ} \mathrm{C}$ & $28-30$ & 29.3 & 31.4 & 29.1 \\
\hline $\mathrm{pH}$ & & $6-9$ & 7.9 & 8.2 & 8.7 \\
\hline DO & $\mathrm{mg} / \mathrm{L}$ & 3 & 5.1 & 4.8 & 4.7 \\
\hline COD & $\mathrm{mg} / \mathrm{L}$ & 40 & 24.5 & 27.5 & 28.5 \\
\hline
\end{tabular}

Temperature analysis result downstream at the Gembong River ranged from 29.1 $31.4{ }^{\circ} \mathrm{C}$ (Table 5). Based on the Government Regulation of Republic of Indonesia No. 22 in 2021 the optimum temperature for the waters ranges from $28-30{ }^{\circ} \mathrm{C}$. The optimum temperature for the growth of aquatic organism is around $25-35{ }^{\circ} \mathrm{C}$ (Fachrudiana and Rachmadiarti, 2020). Water temperature is necessary indicator of water quality that regulates various biological processes in rivers (Harvey et al., 2011). Temperature fluctuations have been shown to affect the histopathology of sundry fish organ systems. Histopathological biomarkers can be an indicator of the effects of various stressors (including temperature fluctuations) on organisms and are a picture of the health of aquatic ecosystems including fish (Raina et al., 2015).

$\mathrm{pH}$ is an indicator to measure the acidity or alkalinity of water. Therefore, it is used measurement parameter controlling pollution levels. Because water $\mathrm{pH}$ has a significant effect on aquatic metabolism (Carvalho et al., 2020). The results of the $\mathrm{pH}$ analysis downstream of the Gembong River ranged from 7.9 - 8.7 (Table 5). pH is still in the optimal range for fish growth. Based on the Government Regulation of Republic of Indonesia No. 22 
in 2021 the optimum $\mathrm{pH}$ for the waters ranges from 6 - 9. Fish will experience stress or even death at $\mathrm{pH} 4$ and 11 because the water conditions are too acidic and alkaline (Ndubuisi et al., 2015). A high-level $\mathrm{pH}$ causes increasing toxicity in the waters, but a low-level pH can inhibit the growth rate of fish (Caesar et al., 2021).

Dissolved oxygen values downstream at the Gembong River ranged from $4.7-5.1$ $\mathrm{mg} / \mathrm{L}$ (Table 5). The oxygen level is still optimal for fish growth. Based on the Government Regulation of Republic of Indonesia No. 22 in 2021 the minimum DO limit in the waters is 3 $\mathrm{mg} / \mathrm{L}$. Dissolved oxygen is a limiting factor for most aquatic organisms because oxygen is prominent in the respiration process. Therefore, dissolved oxygen is the key to water quality and fish health (Franklin, 2014). Factors that affect DO concentration in water include organic compounds, water mixing time, temperature, flow, and water depth (Pribadi et al., 2017).

Chemical Oxygen Demand (COD) is a significant parameter of the amount of oxygen needed to reduce pollutants (Saleh and Kayi, 2021). COD values downstream at the Gembong River ranged from $24.5-28.5 \mathrm{mg} / \mathrm{L}$ (Table 5). This value is still optimal for waters. Based on the Government Regulation of Republic of Indonesia No. 22 in 2021 the optimum COD for the waters is $40 \mathrm{mg} / \mathrm{L}$. Mostly COD is consumed by microorganisms that cause depletion of oxygen content in water. This depletion harms the aquatic environment if the oxygen content falls below the level necessary to support the life of aquatic organisms (Mansour et al., 2017).

\section{CONCLUSION}

The content of heavy metal $\mathrm{Cd}$ in water and Mystus nigriceps organs in the downstream waters at the Gembong River has exceeded the water quality standard. This research proves that the waters contaminated with heavy metal levels of Cd supports histopathological damage to Mystus nigriceps with mild to moderate damage. The higher the level of $\mathrm{Cd}$ in the water, the histopathological damage to the organs was also higher.

\section{ACKNOWLEDGEMENTS}

This research was carried out well thanks to the assistance of various parties, especially supervisors, comrades in arms, and the community around Sungai Gembong, Pasuruan, East Java, and local fisherman who have facilitated the research site. Therefore, the researcher would like to thank you for the support given to this research.

\section{REFERENCES}

1. Abiona, O. O., Anifowose, A. J., Awojide, S. H., Adebisi, O. C., Adesina, B. T., and Ipinmoroti, M. O. (2019). Histopathological biomarking changes in the internal organs of Tilapia ( Oreochromis niloticus ) and catfish ( Clarias gariepinus ) exposed to heavy metals contamination from Dandaru pond, Ibadan, Nigeria . Journal of Taibah University for Science, 13(1), 903-911. https://doi.org/10.1080/16583655.2019.1658400.

2. Anggitasari, L., Suprapto, H., and Nindarwi, D. D. D. (2019). Change in Two-Spot Catfish Histopathological Liver (Mystus nigriceps) Accumulated with Heavy Metal Cadmium (Cd) in Ketingan Estuary, Sidoarjo - East Java, Indonesia. IOP Conference Series: Earth and Environmental Science, 236(1), 1-7. https://doi.org/10.1088/1755-1315/236/1/012105.

3. Baharom, Z. S., and Ishak, M. Y. (2015). Determination of Heavy Metal Accumulation in Fish Species in Galas River, Kelantan and Beranang Mining Pool, Selangor. Procedia Environmental Sciences, 30, 320-325. https://doi.org/10.1016/j.proenv.2015.10.057.

4. Caesar, N. R., Yanuhar, U., Raharjo, D. K. W. P., and Junirahma, N. S. (2021). Monitoring of water quality in the catfish (Clarias sp.) farming in Tuban Regency. IOP Conference Series: Earth and Environmental Science, 718(1), 1-5. https://doi.org/10.1088/1755-1315/718/1/012061.

5. Camargo, M. M. P., and Martinez, C. B. R. (2007). Histopathology of gills, kidney and liver of a Neotropical fish caged in an urban stream. Neotropical Ichthyology, 5(3), 327- 
336. https://doi.org/10.1590/S1679-62252007000300013.

6. Carvalho, T. L. A. de B., Nascimento, A. A. Do, Gonçalves, C. F. D. S., Dos Santos, M. A. J., and Sales, A. (2020). Assessing the histological changes in fish gills as environmental bioindicators in paraty and sepetiba bays in Rio de Janeiro, Brazil. Latin American Journal of Aquatic Research, 48(4), 590-601. https://doi.org/10.3856/vol48issue4-fulltext-2351.

7. Fachrudiana, A. A., and Rachmadiarti, F. (2020). The Diversity of Tolerant Fish in the Coastal Waters of Lusi Island Sidoarjo Regency. Journal of Physics: Conference Series, 1899(1), 1-8. https://doi.org/10.1088/1742-6596/1899/1/012026.

8. Ferro, J. P., Ferrari, L., and Eissa, B. L. (2021). Acute toxicity of cadmium to freshwater fishes and its relationship with body size and respiratory strategy. Comparative Biochemistry and Physiology, 248(5), 1-7. https://doi.org/10.1016/j.cbpc.2021.109109.

9. Franklin, P. A. (2014). Dissolved oxygen criteria for freshwater fish in New Zealand: A revised approach. New Zealand Journal of Marine and Freshwater Research, 48(1), 112126. https://doi.org/10.1080/00288330.2013.827123.

10. Hadi, A. A., and Alwan, S. F. (2012). Histopathological changes in gills, liver and kidney of fresh water fish, Tilapia zillii, exposed to aluminum. International Journal of Pharmacy and Life Sciences, 3(11), 2071-2081.

11. Harvey, R., Lye, L., Khan, A., and Paterson, R. (2011). The influence of air temperature on water temperature and the concentration of dissolved oxygen in Newfoundland Rivers. Canadian Water Resources Journal, 36(2), 171-192. https://doi.org/10.4296/cwrj3602849.

12. Hossain, Z., Hossain, M. S., Ema, N. S., and Omri, A. (2021). Heavy metal toxicity in Buriganga river alters the immunology of Nile tilapia (Oreochromis niloticus L). Heliyon, 1-25. https://doi.org/10.1016/j.heliyon.2021.e08285.

13. Hussain, B., Sultana, T., Sultana, S., Masoud, M. S., Ahmed, Z., and Mahboob, S. (2018). Fish eco-genotoxicology: Comet and micronucleus assay in fish erythrocytes as in situ biomarker of freshwater pollution. Saudi Journal of Biological Sciences, 25(2), 393-398. https://doi.org/10.1016/j.sjbs.2017.11.048.

14. KKS Pasuruan, K. (2015). Strategi Sanitasi Kota Pasuruan Tahun 2016 - 2020. 1-231.

15. Madhulatha, T., and Rajyasree, M. (2019). Effect of Single Super Phosphate on Histopathological Aspects of Fish Channa Striatus. International Journal of Advanced Research, 7(5), 905-909. https://doi.org/10.21474/ijar01/9113.

16. Mansour, O., Idris, M., Noor, N. M., Ruslan, M. S. B., and Das, S. K. (2017). Effects of organic and commercial feed meals on water quality and growth of Barbonymus schwanenfeldii juvenile. AACL Bioflux, 10(5), 1037-1048.

17. Mohammed, S. ., I, O. F., M.K, S., and Abd El-Halim, M. I. (2016). Effect of Some Heavy Metal on Histological Structural of Gills and Liver of Rabbit Fish (Siganus rivulatus) from Two Sites Along Red Sea Coast, SUDAN. International Journal of Advanced Research, 4(6), 1040-1050.

18. Mustafa, S. A. (2020). Histopathology and heavy metal bioaccumulation in some tissues of Luciobarbus xanthopterus collected from Tigris River of Baghdad, Iraq. Egyptian Journal of Aquatic Research, 46(2), 123-129. https://doi.org/10.1016/j.ejar.2020.01.004

19. Ndubuisi, U., Chimezie, A., Chinedu, U., Chikwem, I., and Alexander, U. (2015). Effect of $\mathrm{pH}$ on the growth performance and survival rate of Clarias gariepinus fry. International Journal of Research in Biosciences, 4(3), 14-20.

20. Peraturan Pemerintah No. 22. 2021. Penyelenggaraan Perlindungan dan Pengelolaan Lingkungan Hidup. Sekretariat Negara Republik Indonesia. Volume 1:483.

21. Pribadi, T. D. K., Syahidah, D., and Harjanti, S. D. (2017). Effect of Temperature Shock on the Triploidization Success Rate of Seurukan Fish (Osteochilus vittatus). Biosaintifika: Journal of Biology \& Biology Education, 9(2), 289-297. https://doi.org/10.15294/biosaintifika.v9i2.8680.

22. Puntoriero, M. L., Fernández Cirell, A., and Volpedo, A. V. (2018). Histopathological changes in liver and gills of Odontesthes bonariensis inhabiting a lake with high concentrations of arsenic and fluoride (Chasicó Lake, Buenos Aires Province). Revista 
Internacional de Contaminacion Ambiental, 34(1), 69-77. https://doi.org/10.20937/RICA.2018.34.01.06.

23. Raina, S., Sachar A, Gupta K, S, R., and Sachar, A. (2015). Temperature fluctuations induced histopathological alterations in the liver of fish, Labeo boga inhabiting Jammu waters. International Journal of Fisheries and Aquatic Studies IJFAS, 2(24), 12-16.

24. Safitri, V., Izmiarti, and Nurdin, J. (2019). The Perifiton Alga Community in Masang Kecil River Receives Liquid Palm Oil Mill Waste in Kinali District, West Pasaman Regency. Journal Biology University of Andalas, 7(2), 100-108. http://scholar.unand.ac.id/42285/

25. Saha, N., Rahman, M. S., Ahmed, M. B., Zhou, J. L., Ngo, H. H., and Guo, W. (2016). Industrial metal pollution in water and probabilistic assessment of human health risk. Journal of Environmental Management, 25, 1-9. https://doi.org/10.1016/j.jenvman.2016.10.023.

26. Saleh, B. A., and Kayi, H. (2021). Prediction of Chemical Oxygen Demand from the Chemical Composition of Wastewater by Artificial Neural Networks. Journal of Physics: Conference Series, 1818(1), 1-11. https://doi.org/10.1088/1742-6596/1818/1/012035.

27. Senarat, S., Kettratad, J., Poolprasert, P., Yenchum, W., and Jiraungkoorskul, W. (2015). Histopathological finding of liver and kidney tissues of the yellow mystus, hemibagrus filamentus (Fang and chaux, 1949), from the Tapee River, Thailand. Songklanakarin Journal of Science and Technology, 37(1), 1-5.

28. SNI. (2009). SNI 7387:2009. Batas Maksimum Cemaran Logam Berat dalam Pangan. Batas Maksimum Cemaran Logam Berat Dalam Pangan, 17. https://sertifikasibbia.com/upload/logam_berat.pdf.

29. Sulistyawati, Suyatna, I., Rafii, A., and Ghitarina, G. (2020). Heavy Metals Contents and Histopathological Analysis of Some Organs of Fish Obtained from Payau River, Anggana, Kutai Kartanegara, Indonesia. Journal of Wetlands Environmental Management, 8(2), 149-157. https://doi.org/10.20527/jwem.v8i2.217. 